\title{
Comparative Effects of Selected Agrochemicals on Biochemical Profile and Histopathology of Grass-Carp (Ctenopharyngodon idella)
}

\author{
Muhammad Fiaz Khan', Munawar Saleem Ahmad², Shehzad Ghayyur', \\ Sajid Mahmood ${ }^{1}$, Naveed Akhtar ${ }^{3 *}$, Zaib Ullah ${ }^{3}$, Sadia Tabassum ${ }^{1}$, Samina Yasmin ${ }^{1}$, \\ Khan Dil Badshah ${ }^{4}$, Haroon Hussain ${ }^{5}$, Saira ${ }^{2}$, Alia Gul ${ }^{6}$
}

${ }^{1}$ Department of Zoology, Hazara University, Mansehra, Pakistan ${ }^{2}$ Department of Zoology, University of Swabi, Pakistan

${ }^{3}$ Department of Zoology, Hazara University, Mansehra, Sub Campus Battagram, Pakistan

${ }^{4}$ Department of Chemistry, Government Post Graduate College Haripur, Pakistan ${ }^{5}$ School of Biological Sciences, University of the Punjab, Quaid-e-Azam Campus Lahore, Pakistan

${ }^{6}$ Department of Botany, Hazara University, Mansehra, Pakistan

Received: 13 February 2021

Accepted: 10 September 2021

\begin{abstract}
The current study was designed to evaluate the comparative effects of three selected chemicals such as emamectin (insecticide), acetochlor (herbicide) and topsin-M (fungicide) on haematology, biochemical profile and histopathology of grass carp (Ctenopharyngdon idella). A total of forty C. Idella was collected from fish farm Hattian Kamra and transported to the Chemistry lab of Government Post Graduate College Haripur in plastic bags containing dissolve oxygen. After acclimatization for a week they were randomly segregated in four groups (E0, E1, E2 and E3) and treated with 5ppb emamectin, acetochlor and topsin-M respectively. After $96 \mathrm{hrs}$ of chemical treatment, blood and tissue samples were collected from both control and treated groups for investigation of biochemical and histopathological alterations. Obtained results exhibited significant alteration in haematological parameters i.e. total white blood cells count, $\mathrm{MCV}, \mathrm{MCH}$ and number of platelets significantly $(\mathrm{p}<0.05)$ increased while Red blood cells count, hemoglobin, PCV and MCHC significantly $(p<0.05)$ decreased in the experimental groups E1, E2 and E3 as compared to control group. Significant $(p<0.05)$ changes were observed in biochemical parameters i.e. increase in serum glucose, bilirubin, albumins, blood urea, uric acid, cholesterol, serum calcium, phosphorous, sodium, potassium, serum lipase, CKP, LDH and CK MB, while significant decrease in creatinine, triglycerides, HDL-cholesterol, serum iron, serum amylase, SGPT, alkalinity and Phosphate was observed. The observed Histopathological changes in gills include epithelial
\end{abstract}

e-mail: naveed_zoology@hu.edu.pk 
lifting, destruction of cartilage core, curling, atrophy, loss and fusion of secondary gill lamellae. In liver tissue, the observed variations were necrosis, pyknosis, lymphocytes infiltration, dissolution of plasma membrane, blood congestion and vacuolation. In tissues of intestine, the alterations found were goblet cell formation, rupturing of villi, necrosis and pyknosis. In heart tissues, histopathological changes included blood congestion, necrosis, pyknosis and vacuolation. It could be concluded that these selected chemicals have a strong tendency to bring variations in haematology, biochemical profile and histopathology of Ctenopharyngdon idella.

Keywords: fish, grass carp, agrochemicals, biochemistry, histopathology

\section{Introduction}

Synthetic pesticides are frequently used in agricultural practices to promote the crop production and high yield by eradicating, preventing, repelling insects and pests [1]. But the constant use of these agrochemicals affects the non-targeted species and proved to be hazardous for the life of fish. Besides this they also contaminate our environment. These pesticides through surface run off reach to unbounded areas like rivers, lake and ponds and change the physical and chemical properties of water, hence the aquatic organisms affected from this [2]. So, these pesticides directly or indirectly affect fishes. Ultimately aquatic environment get polluted by extensive use of pesticides. Chemically, the major groups of pesticides that are commonly used in fields include: Organochlorine, carbamates, organophosphate, trizole, pyrethroids, and nicotinoids [3]. According to their target use, pesticides or agrochemicals are also categorized into various classes of compounds including herbicides, insecticides, fungicides, nematocides, mollucicides, rodenticides, plant growth regulators and various other. Among these categories there are three major classes of pesticides i.e. insecticide, herbicide and fungicide [4].

Emamectin, a 16-membered macrocyclic lactone, produced from the soil Streptomyces avermitilis bacterium by the fermentation [5]. Acetochlor is a member of class chloroacetinilides compound. It is used in soya bean, corn, sorghum and peanuts to provide them high organic content by the destruction of grasses and large leaf weeds. The fungicide Topsin-M is a systematic fungicide and member of the benzimidazole group of fungicides that is absorbed by the roots and leaves of treated plants [6].

Because of its well organized nervous, osmoregulatory, immune and endocrine systems, fish is highly recommend as experimental organism in research [7]. Besides these attributes, fish also display high sensitivity to oscillations that occur in their outside environment, as compared to the invertebrates. Fish also have a potential to bioaccumulate the toxic elements in elevated concentration in contrast to surrounding water. All these imputations of fish support it to be used as bioindicator and suitable biomarker eco-toxicology in contrast to other vertebrates and invertebrates $[8,9]$. The pesticides accumulation in the important organs, including liver and muscles may leads to organ dysfunction resulting in demise of the fish. Similarly, efficiency of some enzyme indispensable for metabolic purposes of fish may be altered [10]. The histopathological investigations on different tissues of fish are valuable tools for toxicology studies and monitoring water pollutions. The histopathological investigations can provide information about the health and functionality of organs in the animals like fish [11].

Farmers use pesticides on large scale to get desirable yield in Pakistan [12]. The accumulation of these pesticides into water bodies without proper checking and monitoring may pose enormous toxic effects on non-target species of animal including fish. Afterwards, fish being commercially important and vital part of the food chain, become inedible due to the toxicity caused by pesticides. The current study is to check the comparative effect of three selected Agrochemicals i.e. emamectin, acetochlor and topsin-M on hematology, biochemical profile and histopathology of grass carp.

\section{Materials and Methods}

\section{Procurement of Fish and Pesticides}

A total of forty grass carp (C. idella) specimen, each 7-8 inches in size was collected from fish Hattian farm Kamra using hand net and were kept in plastic bag containing oxygenated water and transported to the Chemistry lab of Government Post Graduate College Haripur for further experimental work. All the collected fish were transported to laboratory within 4 hours after catching, to reduce the stress on fish. After that fish were allowed to adapt the laboratory conditions for one week prior to experiment. Fish were kept in aerated glass aquarium having capacity of 60-liter. The aquaria were filled with tap water possessing temperature $20-23^{\circ} \mathrm{C}, \mathrm{pH} 7$ and were fitted with oxygen pump to maintain the oxygen level. Fish were fed daily with $5 \%$ body weight with commercial food. Aquarium water was changed on daily bases. 5 ppb stock solution of emamectin, acetochlor and topsin-M were prepared from chemical formulation. Four glass aquaria of 60 liter water capacity were filled up to 40-liter of tap 
water. Eight randomly selected fish were placed in each aquarium. Selected fish were subjected to $5 \mathrm{ppb}$ solution of emamectin, acetochlor and topsin-M in three of the aquaria labeled as E1, E2 and E3 respectively. E0 served as control group. Water and chemical solutions were changed daily during the entire period of experimentation.

\section{Physio-Chemical Parameters of Water}

The physical and chemical parameters included temperature $\left(23 \pm 1.29^{\circ} \mathrm{C}\right), \mathrm{pH} \quad(7.4 \pm 0.22)$, dissolved oxygen $(6.3 \pm 0.51 \mathrm{mg} / \mathrm{L})$, total alkalinity $(131 \pm 4.90 \mathrm{mg} / \mathrm{L})$, chloride $(12.6 \pm 2.2 \mathrm{mg} / \mathrm{L})$, calcium hardness $(43 \pm 1.53)$ and conductivity $(0.818 \pm 0.8 \mathrm{mS} / \mathrm{cm})$ which were measured by mercury bulb thermometer, digital $\mathrm{pH}$ meter, DO meter, multi direct $\mathrm{PC}$ and $\mathrm{mg} / \mathrm{L}$ and conductivity meter respectively.

\section{Behavioral Study}

During 96 hrs of experimentation time, the behavior including swimming, operculum movement, jumping, feeding etc. of grass carp control and treated groups which were exposed to three different chemicals (emamectin, acetochlor and topsin-M) was keenly observed at interval of 12 hours.

\section{Hematology}

Fish from each aquarium were removed, after $96 \mathrm{hrs}$ of exposure and dipped in clove oil to anesthetize. Blood was collected from the caudal fin using expendable Syringe coated with heparin and was stored in EDTA tubes in order to prevent them from clotting. Collected blood samples were tested for determining different parameters like red blood cells (RBCs) count, white blood cells (WBCs) count, hemoglobin, hematocrit, mean corpuscular volume (MCV), mean corpuscular hemoglobin (MCH), mean corpuscular hemoglobin concentration (MCHC) and platelets using hematological analyzer and these parameters were determined from all the experimental and control group [13].

\section{Biochemical Test}

For testing biochemical profile, the blood sample were transferred in clotting tubes in order to clot blood samples at room temperature for $30 \mathrm{mins}$. From the clotted samples, serum was removed by centrifugation for $5 \mathrm{~min}$ at $3000 \mathrm{rpm}$ and then serum was frozen at $20^{\circ} \mathrm{C}$. After that serum was analyzed for biochemical parameters which include metabolites such as total protein, serum glucose, total bilirubin, albumins, blood urea, creatinine, uric acid, cholesterol, triglycerides and HDL-Cholesterol. Also determined serum electrolytes including Serum calcium, phosphorous, sodium, potassium, iron and beside this some enzymes like serum amylase, serum lipase, alkaline phosphatase, alanine transaminase (ALT), creatine phosphokinase (CKP), lactate dehydrogenase (LDH) and creatine kinase muscle brain (CK MB) were found in bloodserum [14].

\section{Histopathology}

For histopathological study, same fish which were previously used in hematology and biochemical test, were then dissected in order to expose the gills, liver, heart and intestine and organs were placed in formalin solution to prevent them from decaying. After fixation, these organs were allowed to dehydrate in ascending sequence of alcoholic grades in order to remove all traces andthencleared in xylene and anchoredin paraffin wax. After that the slices of about 4-5 mm thickness was cut on a rotary microtome. Then staining was performed using eosin and hematoxylin and scrutinized under camera fitted microscope (OPTIKA B3) [15].

\section{Statistical Analysis}

Hematological and biochemical data was analyzed using SPSS software. One-way ANOVA test was applied for the comparison between all the experimental groups. Variables were recounted as mean and standard deviation. $\mathrm{P}<0.05$ was set as a level of significance.

\section{Results}

\section{Study of Fish Behavior}

In all the three experimental groups, fish exposed to different chemicals, showed abnormal behavior. Sign of stress, jumping of fish from aquarium, loss of body equilibrium, upward swimming in experimental groups compared to control was noticed.

\section{Hematology}

Hematological result shows that Total white blood cells count, $\mathrm{MCV}, \mathrm{MCH}$ and number of platelets increased in all the three experimental groups exposed to selected chemicals (emamectin, acetochlor and topsin-M) as compared to control as shown in Table 1, while Red blood cells count, hemoglobin, PCV and $\mathrm{MCHC}$ decreased in the experimental groups E1, E2 and E3 as compared to control group as shown in Fig. 1.

\section{Biochemical Profiling}

The observed biochemical parameter significantly increased or decreased in the experimental group as compared to the control group. In metabolites, serum glucose, bilirubin, albumins, blood urea, 
Table 1. Biochemical Parameters of Control and Experimental Groups.

\begin{tabular}{|c|c|c|c|c|}
\hline Biochemical Parameters & Control group & $\begin{array}{c}\text { E1 } \\
\text { (Emamectin) }\end{array}$ & $\begin{array}{c}\text { E2 } \\
\text { (Acetochlor) }\end{array}$ & $\begin{array}{c}\text { E3 } \\
\text { (Topsin-M) }\end{array}$ \\
\hline \multicolumn{5}{|c|}{ Metabolites } \\
\hline Serum Protein (G/dl) & $22.32 \pm 1.31$ & $5.46 \pm 1.38^{* \Delta}$ & $12.5 \pm 1.40{ }^{*} \Delta$ & $17.12 \pm 1.63{ }^{* \Delta}$ \\
\hline Serum Glucose (mg/dl) & $40.40 \pm 4.15$ & $100.0 \pm 5.0^{*} \Delta$ & $78.2 \pm 6.61{ }^{* \Delta}$ & $56.8 \pm 4.14^{* \Delta}$ \\
\hline Total Bilirubin (md/dl) & $0.064 \pm 0.035$ & $2.14 \pm 0.20^{* \Delta}$ & $1.22 \pm 0.19^{* \Delta}$ & $0.70 \pm 0.15^{* \Delta}$ \\
\hline Albumins (G/dl) & $3.44 \pm 0.444$ & $11.28 \pm 1.08$ & $8.42 \pm 0.46^{*}$ & $5.62 \pm 0.74^{*}$ \\
\hline Blood urea (mg/dl) & $0.90 \pm 0.339$ & $8.02 \pm 0.55^{* \Delta}$ & $5.48 \pm 0.71 * \Delta$ & $2.94 \pm 0.87{ }^{*} \Delta$ \\
\hline Creatinine (mg/dl) & $1.28 \pm 0.117$ & $0.34 \pm 0.12 * \Delta$ & $0.79 \pm 0.06 * \Delta$ & $1.09 \pm 0.10^{\Delta}$ \\
\hline Uric Acid (mg/dl) & $0.86 \pm 0.27$ & $5.40 \pm 0.50 * \Delta$ & $3.40 \pm 0.44^{* \Delta}$ & $1.78 \pm 0.37{ }^{*} \Delta$ \\
\hline Cholesterol (mg/dl) & $73.40 \pm 6.42$ & $129.4 \pm 6.06^{* \Delta}$ & $107.4 \pm 6.58^{* \Delta}$ & $52.2 \pm 1.92 * \Delta$ \\
\hline Triglycerides (mg/dl) & $63.80 \pm 4.65$ & $29.60 \pm 5.72 * \Delta$ & $43.8 \pm 4.65^{* \Delta}$ & $54.0 \pm 4.0^{\Delta}$ \\
\hline HDL- Cholesterol (mg/dl) & $59.20 \pm 1.92$ & $34.60 \pm 4.15^{* \Delta}$ & $46.2 \pm 1.92 * \Delta$ & $52.2 \pm 1.92 * \Delta$ \\
\hline \multicolumn{5}{|c|}{ Electrolytes } \\
\hline Serum Calcium (mg/dl) & $0.12 \pm 0.050$ & $1.2 \pm 0.15^{* \Delta}$ & $0.70 \pm 0.15^{*} \Delta$ & $0.34 \pm 0.09 * \Delta$ \\
\hline Phosphorous (N-D) & $2.52 \pm 0.349$ & $12.4 \pm 1.55^{* \Delta}$ & $7.68 \pm 1.53{ }^{*} \Delta$ & $4.26 \pm 0.55 * \Delta$ \\
\hline Sodium $(\mathrm{mmol} / \mathrm{l})$ & $77.0 \pm 3.67$ & $138.6 \pm 6.02{ }^{*} \Delta$ & $111.8 \pm 6.68{ }^{* \Delta}$ & $92.4 \pm 6.18^{* \Delta}$ \\
\hline Potassium (mmol/l) & $2.96 \pm 0.45$ & $12.4 \pm 1.43{ }^{*} \Delta$ & $8.06 \pm 0.92 * \Delta$ & $4.98 \pm 0.47^{*} \Delta$ \\
\hline Serum Iron $(\mu \mathrm{g} / \mathrm{dl})$ & $51.34 \pm 25.73$ & $38.6 \pm 2.70$ & $38.6 \pm 2.70$ & $38.6 \pm 2.70$ \\
\hline \multicolumn{5}{|c|}{ Enzymes } \\
\hline Serum Amylase $(\mu / \mathrm{L})$ & $6.0 \pm 1.58$ & $32.0 \pm 3.87^{* \Delta}$ & $19.6 \pm 3.64{ }^{* \Delta}$ & $10.0 \pm 1.58^{\Delta}$ \\
\hline Serum Lipase (N-D) & $2.52 \pm 0.349$ & $12.0 \pm 1.58^{* \Delta}$ & $7.50 \pm 1.11^{* \Delta}$ & $4.16 \pm 0.61^{* \Delta}$ \\
\hline SGPT (ALT) (U/L) & $51.8 \pm 2.3874$ & $29.2 \pm 2.58{ }^{* \Delta}$ & $37.8 \pm 1.92 * \Delta$ & $46.0 \pm 1.58{ }^{* \Delta}$ \\
\hline Alk. Phosphatase (U/L) & $15.5 \pm 1.11$ & $5.18 \pm 1.32 *^{*}$ & $9.70 \pm 1.20 * \Delta$ & $13.04 \pm 0.82{ }^{*} \Delta$ \\
\hline $\mathrm{CKP}(\mathrm{U} / \mathrm{l})$ & $142.6 \pm 14.67$ & $297.8 \pm 4.65^{* \Delta}$ & $221.0 \pm 10.3{ }^{* \Delta}$ & $221.0 \pm 10.3^{* \Delta}$ \\
\hline LDH (U/l) & $918.2 \pm 22.7$ & $516.8 \pm 26.9^{* \Delta}$ & $1022.6 \pm 17.4{ }^{* \Delta}$ & $1024.6 \pm 16.9^{* \Delta}$ \\
\hline CK MB (U/l) & $256.4 \pm 29.7$ & $433.4 \pm 29.5^{*}$ & $441.0 \pm 23.5^{*}$ & $442.4 \pm 23.3^{*}$ \\
\hline
\end{tabular}

Mean \pm SD with symbol * shows significant difference $(\mathrm{p}<0.05)$ between control and experimental groups while symbol ${ }^{\Delta}$ shows $^{\circ}$ significant intergroup difference between the experimental groups.

uric acid and cholesterol significantly $(\mathrm{p}<0.05)$ increased while creatinine, triglycerides and HDLcholesterol significantly $(\mathrm{p}<0.05)$ decreased in all the experimental groups as compared to the control group. In electrolytes, Serum calcium, phosphorous, sodium and potassium significantly increased, whereas serum iron significantly decreased in experimental groups as compared to control group. Among enzymes, serum amylase, lipase, CKP, LDH and CK MB significantly increased while SGPT and Alk phosphate significantly decreased in experimental group as compared to control group as shown in Table 1.

\section{Histopathology}

\section{Control Gills Tissue}

Under microscope the gills tissue section of control group of grass carp exhibited normal construction of gill filaments, having central cartilaginous core and thin epithelial covering of primary and secondary gills lamella and thin lining of stratiform epithelium containing chloride cell and mucous cells as shown in Fig. 2 (G1, G2). 

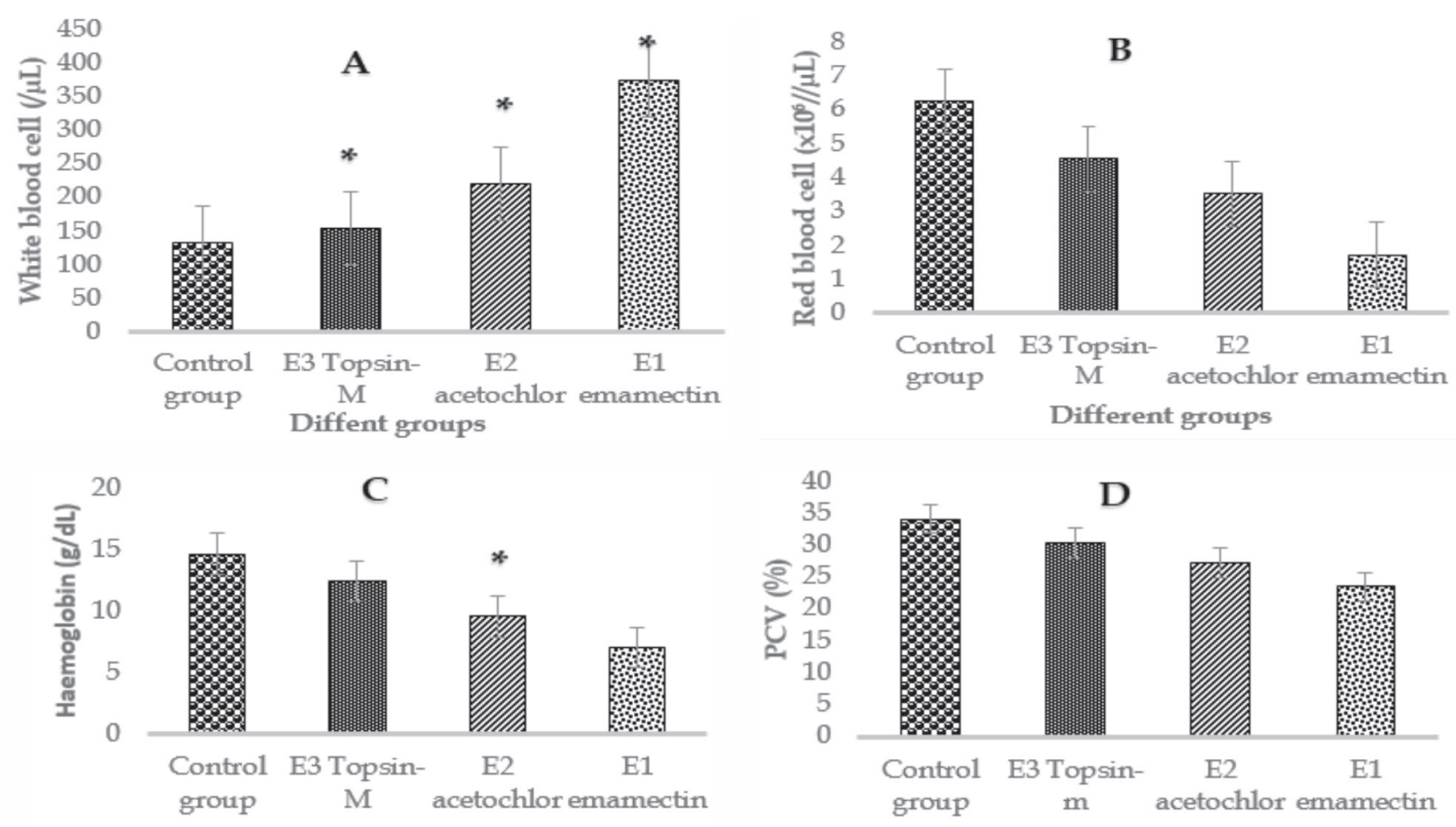

Different groups
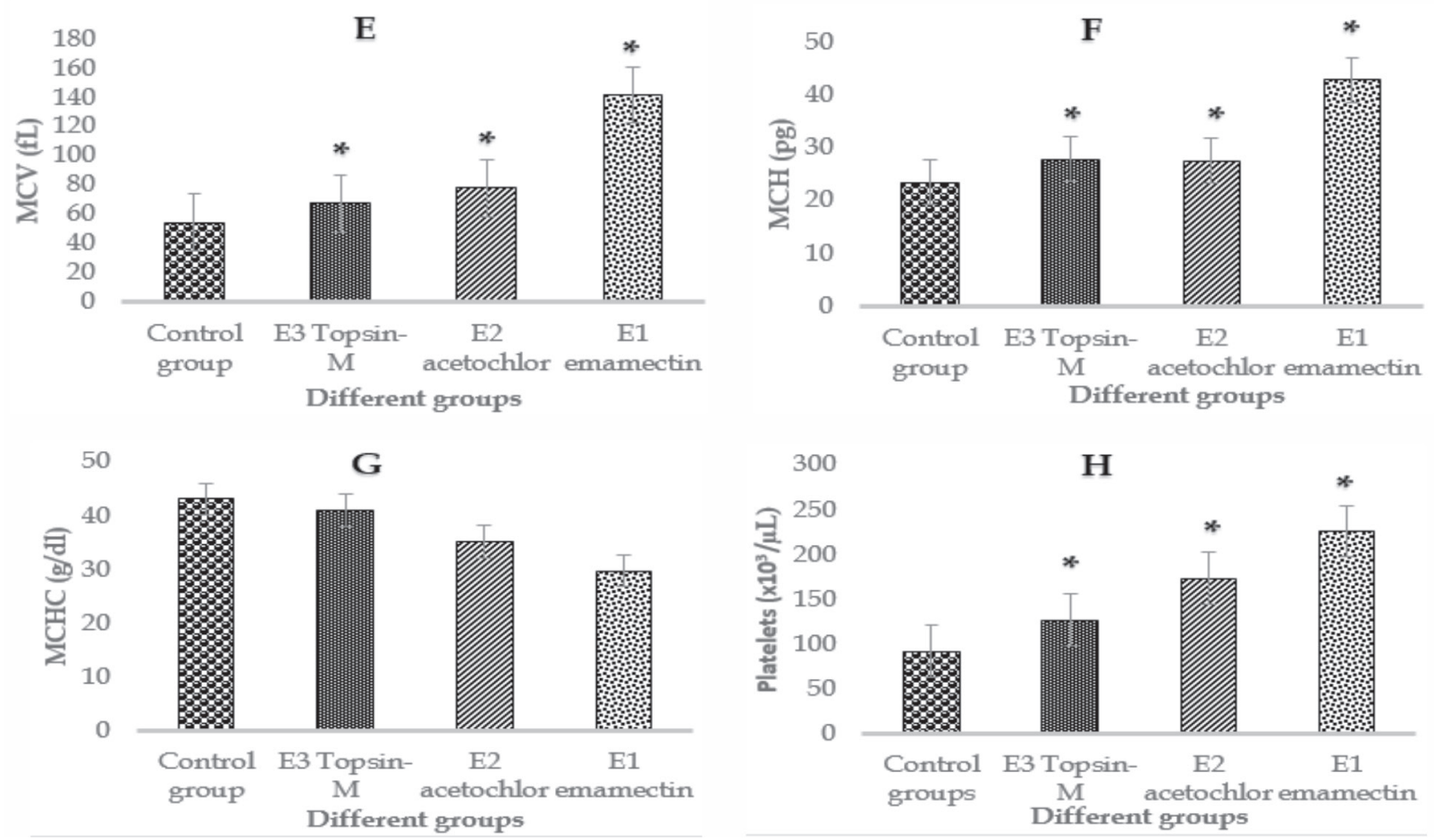

Fig 1. (A-H) Graphical description of the comparative effect of three selected chemicals (Emamectin, Acetochlor and topsin-M) and comparison with control group on haematological parameters of fish. $\left({ }^{*}\right)$ shows significant difference $(p<0.05)$ to each other.

\section{Experimental Gills Tissue}

Histopathological results of experimental gills tissue revealed that, in experimental group 1 which was exposed to $5 \mathrm{ppb}$ emamectin solution showed destruction of cartilage core, epithelial lifting, curling and atrophy. In experimental group 2 which was exposed to $5 \mathrm{ppb}$ acetochlor solution, showed changes in gills tissue i.e fusion, disruption and loss of secondary gills lamellae along with epithelial lifting, destruction of cartilage core, atrophy and curling. In experimental group 3 which was exposed to $5 \mathrm{ppb}$ topsin-M solution, observed histopathological changes included fusion and loss of secondary lamellae, epithelial lifting, destruction of cartilage core, atrophy and curling Fig. 2 (G3-G7). 

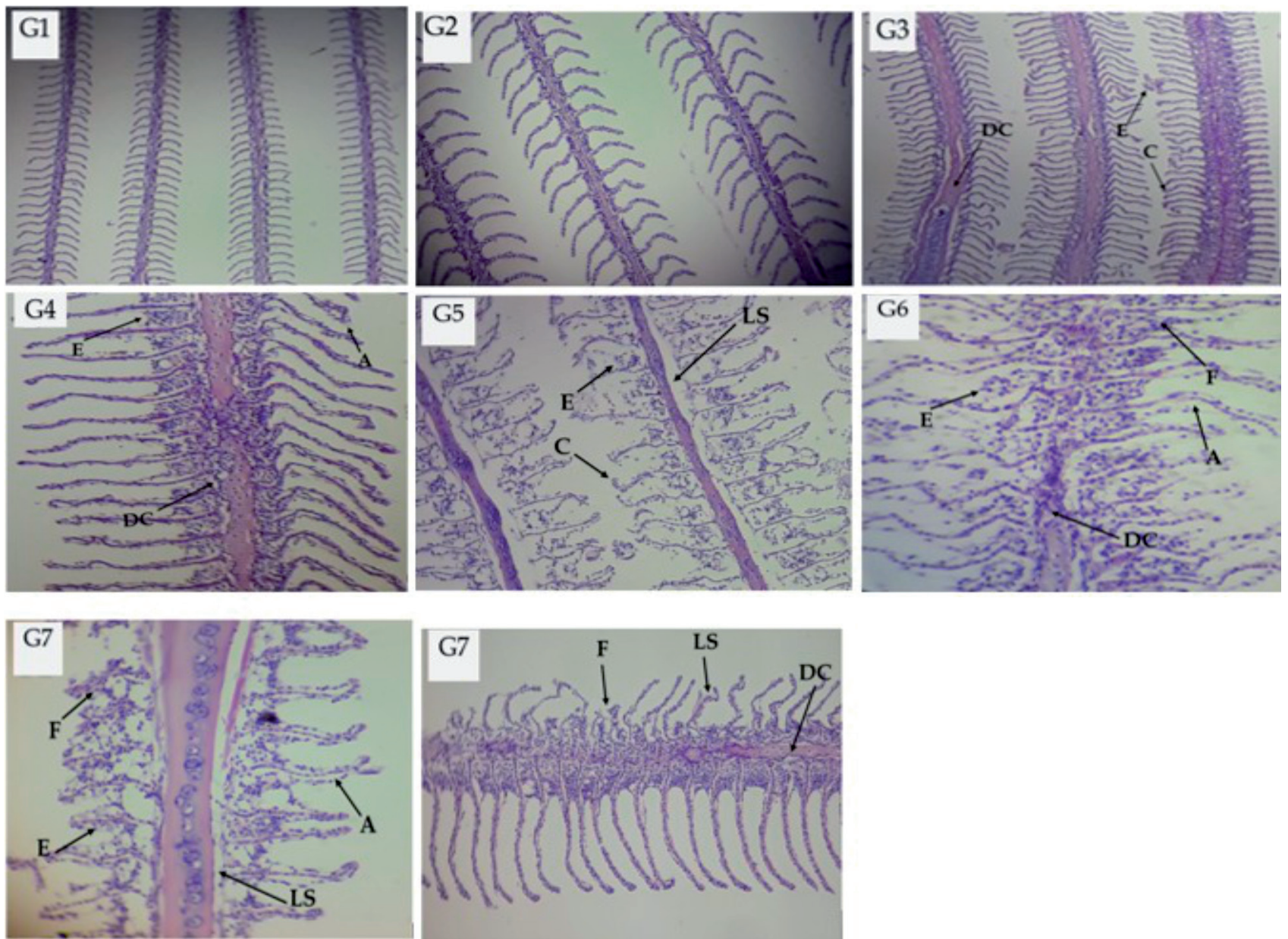

Fig 2. G1-G2 Fish gill tissues of control group. G3-G4 Fish gill tissue exposed to Emamectin solution. G5-G6 Fish gill tissue exposed to Acetochlor solution. G7-G8 Fish gill tissue exposed to Topsin-M solution: Epithelial Lifting (EL), Destruction of Cartilage core (DC), curling (C), atrophy (A), Loss of Secondary gills lamellae (LS), fusion of secondary gills lamellae (FS).

\section{Liver Tissue from Control Group}

Under microscope tissue section of liver of control group grass carp showed normal structure of liver cells. Hepatocyte is round in shape containing clear round nucleus and nucleolus as shown in Fig. 3. (L1-L2).

\section{Liver Tissue from Experimental Group}

In experimental group 1, 5 ppb emamectin solution, hepatocyte showed necrosis, pyknosis, lymphocytes infiltration, dissolution of plasma membrane and vacuolation. In experimental group 2 with $5 \mathrm{ppb}$ acetochlor solution, several histological changes were noticed in hepatocytes i.e blood congestion, dissolution of plasma membrane, necrosis, vacuolation and pyknosis. In experimental group 3 with $5 \mathrm{ppb}$ topsin-M, hepatocyte showed blood congestion, necrosis, vacuolation, dissolution of plasma membrane and lymphocyte infiltration as shown in Fig. 3. (L3-L8).

\section{Intestinal Tissue from Control Group}

Microscopic study of intestinal tissue showed that there was no alteration occurred in the structure of villi in control group. The intestinal villi consist of mucosal epithelium, muscularis mucosa, lamina propria, stratum compactum and serous membrane as shown in Fig 4. (I1-I2).

\section{Intestinal Tissue from Experimental Group}

In experimental group 1 , exposed to $5 \mathrm{ppb}$ emamectin solution, rupturing of villi, goblet cell formation, necrosis and pyknosis was observed. Histopathological changes observed in experimental group 2 which was exposed to $5 \mathrm{ppb}$ acetochlor solution, were goblet cell formation, pyknosis and necrosis. In experimental group 3, exposed to $5 \mathrm{ppb}$ topsin-M solution, the histopathological changes included rupturing of villi, goblet cell formation and necrosisas shown in Fig 4. (I3-I8). 

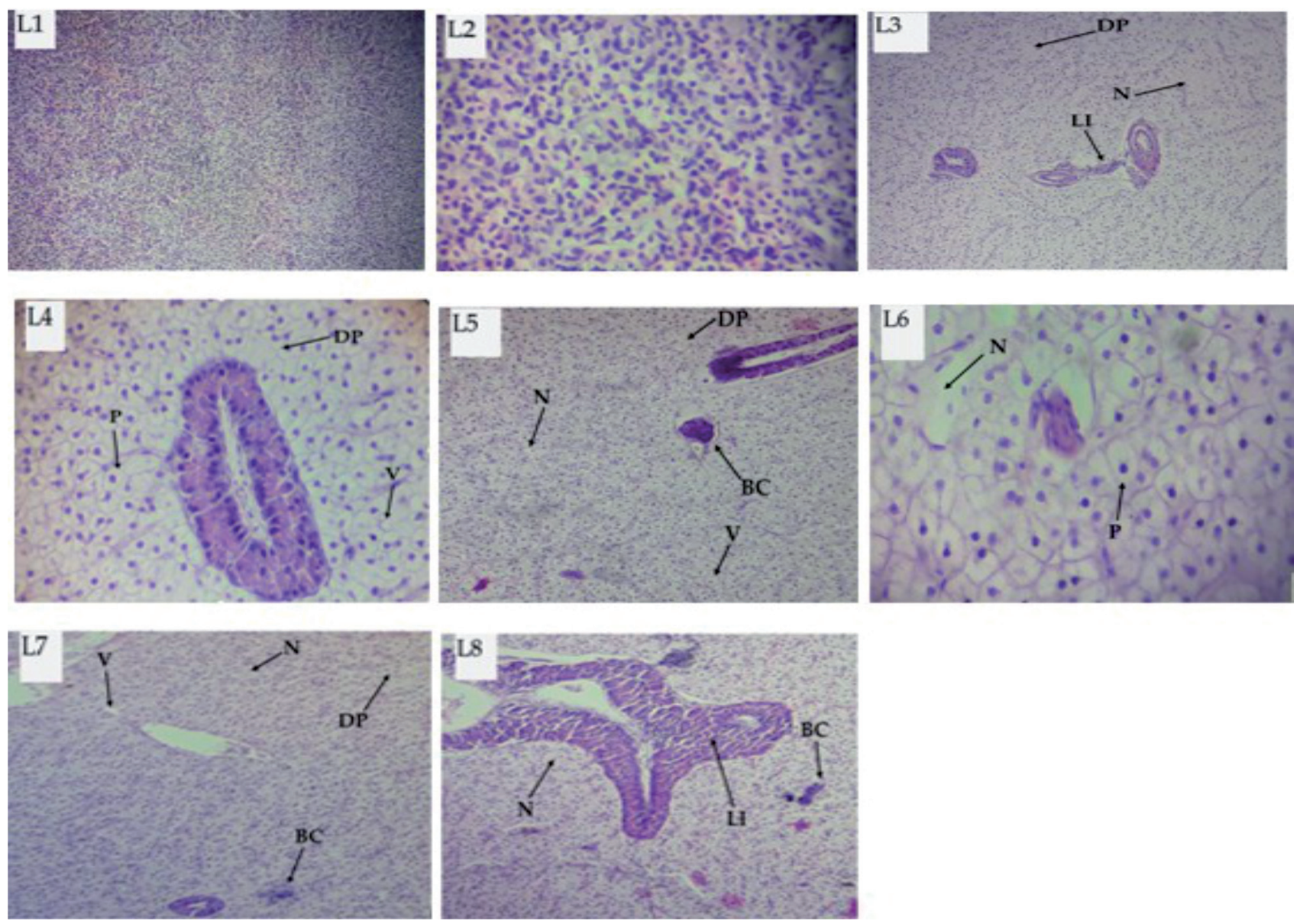

Fig. 3. L1-L2 Fish liver tissues of control group. L3-L4 Fish liver tissue exposed to Emamectin solution. L5-L6 Fish liver tissue exposed to Acetochlor solution. L7-L8. Fish liver tissue exposed to Topsin-M solution: Necrosis (N), Pyknosis (P), Lymphocytes Infiltration (LI), Dissolution of plasma membrane (DP), Blood Congestion (BC) and Vacuolation (V).

\section{Heart Tissue from Control Group}

Microscopic study of heart, revealed that no alteration was observed in the heart tissues of control group as shown in Fig. 5 (H1-H2).

\section{Heart Tissue from Experimental Group}

In experimental group 1 , exposed to $5 \mathrm{ppb}$ emamectin solution, observed histopathological changes included blood congestion, necrosis and pyknosis. In experimental group 2 which was exposed to $5 \mathrm{ppb}$ acetochlor solution, observed changes were necrosis, pyknosis, vacuolation and blood congestion and same changes were observed in experimental group 3 which was exposed to $5 \mathrm{ppb}$ topsin-M solution except blood congestion as shown in Fig 5. (H3-H8).

\section{Discussion}

The present study was carried out to find the comparative effects of selected chemicals such as emamectin, acetochlor and topsin-M on the hematology, biochemical and histopathology of grass carp during acute toxicity. It was $96 \mathrm{hrs}$ experiment and no mortality were observed throughout the experiment. Intoxication of grass carp with $5 \mathrm{ppb}$ concentration of emamectin, acetochlor and topsin-M shows sign of stress on fish like increased excitability, equilibrium loss and upward swimming. Similar results was also reported by [13] in Nile tilapia during chlorpyrifos intoxication and [16] in Common Carp during endosulfan intoxication. Hematological parameters are exceedingly important for estimation of environmental pollutants exposed to organisms and being used as important biomarker [17]. Current study shows significant variations in hematological parameters of all treated group like increased in the count of white blood cells, MCV value, $\mathrm{MCH}$ and number of platelets as compared to the control group. While, certain parameters of blood were found reduced in treated groups due to toxicants such as Red blood cells count, hemoglobin, PCV and $\mathrm{MCHC}$ as compared to control group. Higher variation in the values of hematological parameters observed in emamectin than in acetochlor and slight variations observed in topsin-M. White blood cells play noteworthy role in immunity and the changes with the exposure to 

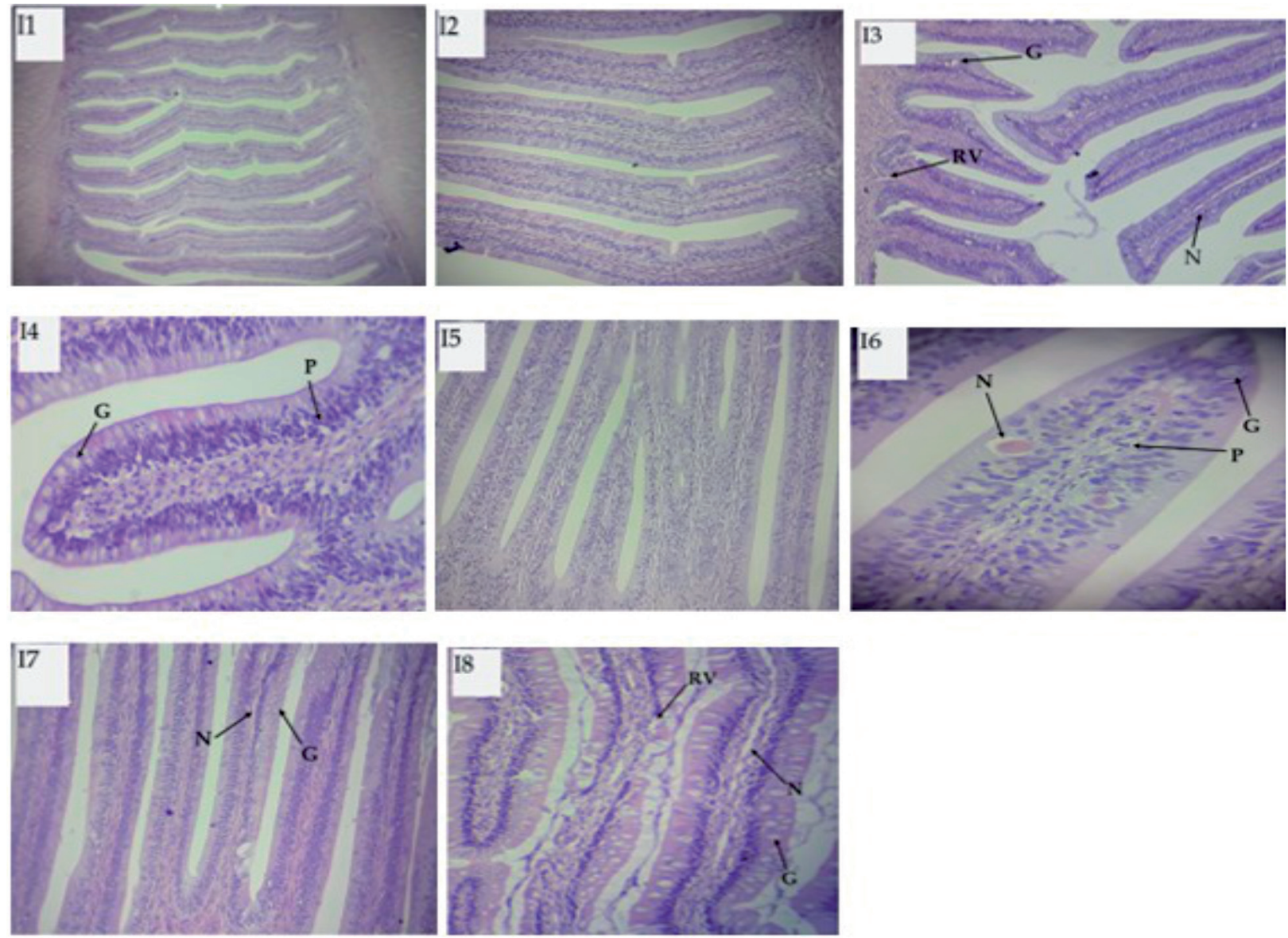

Fig. 4. I1-I2 Fish intestine tissues of control group. I3-I4 Fish intestine tissue exposed to Emamectin solution. I5-I6 Fish intestine tissue exposed to Acetochlor solution. I7-I8 Fish intestine tissue exposed to Topsin-M solution:Globlet cell formation (G), Repturing of Villi $(\mathrm{RV})$, Necrosis $(\mathrm{N})$ and Pyknosis $(\mathrm{P})$.

any chemicals in WBC counts shows an attenuation in nonspecific immunity of the fish. In current study number of leukocytes significantly increased that may be correlated with generalized immune response and a protective response to our selected chemicals. In stress condition, counts of leukocytes increases significantly to subsist with stress condition and shield organism [18]. Our results in which significantly increase in numbers of white blood cells, MCV and MCH value fall in line with the work of [19] on hematological variations due to mixture of atrazine and metachlor exposure on African catfish. One of the crucial component of blood is thrombocyte which plays an important role in blood clotting by absorbing different factors for blood clotting and transport these factors to the area of injury or hemorrhage [20]. Similar hematological alteration was reported in Common Carp by [21] on exposure to phenthoate for 96h. Our results are in agreement with the work of [15], on acute toxicity of endosulfan on grass carp, reported that the number of platelets is significantly increases. [22] reported decreased in $\mathrm{Hb}$ level and other blood components due to RBCs inhibitions, retardation of haemosynthesis, RBCs destruction in hematopoietic organs and osmoregulatory dysfunction in on Catla catla exposed to sub lethal concentration of deltamethrin. Akhtar and his workers also reported decrease in $\mathrm{RBC}$ and hemoglobin in Schizothorax plagiostomus after exposure to atrazine [23]. MCH, MCHC, monocytes and lymphocytes while significantly higher values of HCT and platelets are observed. Hematological examination reported by [24] showed a significant depletion in value of Hemoglobin, Hematocrit, Red Blood Cells, and Mean Corpuscular Hemoglobin Concentration (MCHC). Generally, decrease in hemoglobin level, number of Red Blood Cells and hematocrits might be due to destruction of RBCs and erythroblastosis causing anemia [25]. Significant decrease $(\mathrm{p} \leq 0.05)$ is reported in $\mathrm{RBC}$ count of Schizothorax esocinus after exposure to atrazine [26].

We observed a significant variation in biochemical parameters, in metabolites, significant increase in serum glucose, total bilirubin, albumins, blood urea, uric acid and cholesterol level in all experimental groups were observed. While a significant decreased in value of serum protein, creatinine, triglycerides and HDLcholesterol in all experimental groups (emamectin, acetochlor and topsin-M) as compared to control group, especially in emamectin group which show high toxicity as compared to acetochlor and topsin-M. For the 

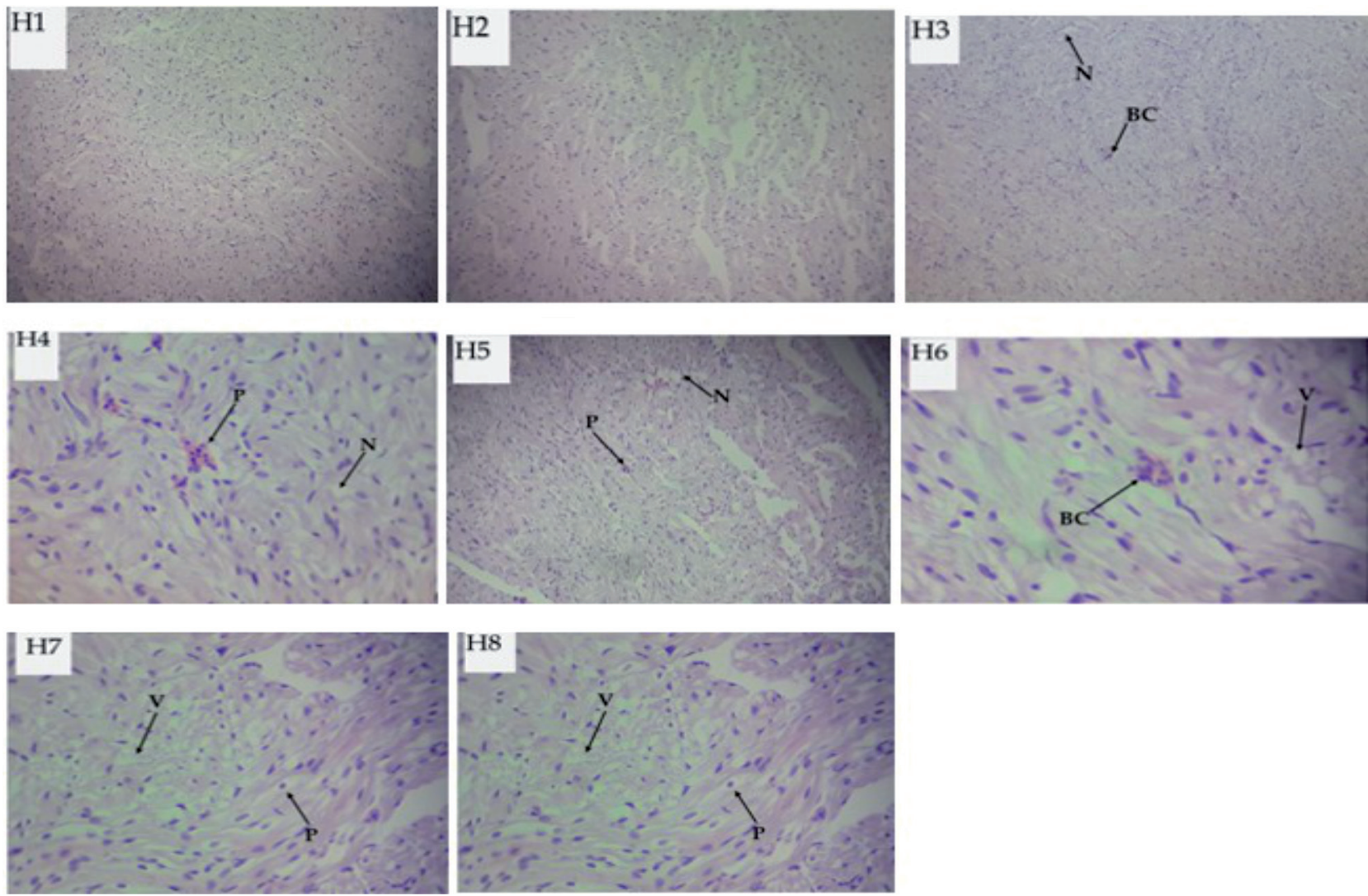

Fig. 5. H1-H2 Fish heart tissues of control group. H3-H4 Fish heart tissue exposed to Emamectin solution. H5-H6 Fish heart tissue exposed to Acetochlor solution. H7-H8 Fish heart tissue exposed to Topsin-M solution:Necrosis (N), Vacuolation (V), Necrosis (N) and Pyknosis.

survival of animal with stress condition hyperglycemia plays vital role by making more energy and supplied to essential organ when they needed [27]. Hyperglycemia observed in exposure groups of L. rohita in contrast to control group which is in line with [21]. This result is in conformity with the work of [28] in which they reported significant increase in blood glucose level in $L$. rohita when they exposed to cypermethrin. Significant increase in the total bilirubin, blood urea, uric acid and cholesterol also shown by the [29] which check the effect of imidacloprid on serum biochemical profile and hematology of $L$. rohita fish. Significant increase is observed in cholesterol and glucose level of $S$. plagiostmous after exposure to atrazine [23]. Similarly glucose level increased in Schizothorax esocinus after exposure to cypermethrin [30]. Significant increase in the number of albumins shown in the current study, our result is an agreement with the work of [31] which evaluate the biochemical, hematological and histopathology of common carp when exposed to herbicide (atrazine). Depletion of serum protein (Hypoproteinemia) also reported by [32] in catfish. The protein concentration could be used as an indicator of general state of fish health and also as an indicator of stress [33]. In the current study significant decreased in level of HDL-cholesterol and triglycerides level were observed, same result shown from 4-day treatment of imidacloprid on L. rohita [29]. Significant changes were observed in the blood electrolytes or minerals of the experimental group of fish. In our results all the electrolytes like serum calcium, phosphorus, sodium and potassium significantly increases except serum iron which decreases indicates in all experimental group (emamectin, acetochlor and topsin-M) as compared to control group. This indicate the hydromineral balance of the fish due to the exposure of these selected chemicals (emamectin, acetochlor and topsin-M). Same result also shown by [34] on biochemical changes by exposure of cypermethrin, reported the significant increase in level of sodium, potassium, magnesium, calcium, phosphorous, glucose, urea and cholesterol and decrease in protein and triglycerides which were aggravated due to stress associated with consequent increase in cortisol level. Among enzymes we observed, significant increase in the concentration of serum amylase, serum lipase, $\mathrm{CKP}, \mathrm{LDH}$ and $\mathrm{CK} \mathrm{MB}$ in the experimental groups compared to control group, while significant decrease in the value of SGPT (ALT) and Alk. ALT or SGPT are found in the liver, when the cells are destroyed because of injuries or disease these enzymes are released into plasma and their concentration is high in plasma and are considered as indicator of abnormal physiology, in our result ALT is significantly decreases. ALP and LDH play a significant role in phosphate hydrolysis, 
Table 2. Summarized Histopathological alteration in the gills, liver, intestine and heart of Grass Carp when exposed to three different concentration of chemicals.

\begin{tabular}{|c|c|c|c|c|}
\hline Histopathological Alteration & Control group & $\begin{array}{c}\text { E1 } \\
\text { (Emamectin) }\end{array}$ & $\begin{array}{c}\mathrm{E} 2 \\
\text { (Acetochlor) }\end{array}$ & $\begin{array}{c}\text { E3 } \\
\text { (Topsin-M) }\end{array}$ \\
\hline \multicolumn{5}{|c|}{ Gill } \\
\hline Epithelial lifting & - & $* *$ & $* *$ & $* * *$ \\
\hline Destruction of Cartilage core & - & $* * *$ & $* *$ & * \\
\hline Curling & - & * & $* *$ & $* *$ \\
\hline Atrophy & - & $* *$ & $* *$ & $* *$ \\
\hline Loss of secondary gill lamellae & - & - & $* *$ & * \\
\hline Fusion of Secondary gill lamellae & - & - & $* *$ & $* * *$ \\
\hline \multicolumn{5}{|c|}{ Liver } \\
\hline Necrosis & - & $* *$ & $* *$ & $* * *$ \\
\hline Pyknosis & - & * & $*$ & - \\
\hline Lymphocyte infilteration & - & * & - & * \\
\hline Dissolution of plasma membrane & - & * & $* *$ & * \\
\hline Vacuolation & - & * & $*$ & $* *$ \\
\hline Blood Congestion & - & $*$ & $* *$ & $* *$ \\
\hline \multicolumn{5}{|c|}{ Intestine } \\
\hline Globlet cell formation & - & $* * *$ & $*$ & $* *$ \\
\hline Repturing of villi & - & * & - & $* *$ \\
\hline Necrosis & - & $* *$ & $* *$ & $* *$ \\
\hline Pyknosis & - & $*$ & $*$ & - \\
\hline \multicolumn{5}{|c|}{ Heart } \\
\hline Blood Congestion & - & * & $*$ & - \\
\hline Necrosis & - & $* *$ & $*$ & * \\
\hline Pyknosis & - & $* *$ & $*$ & $a^{*}$ \\
\hline Vacuolation & - & - & $* *$ & $* *$ \\
\hline
\end{tabular}

Rare $\left(_{*}\right)$, Frequent $\left({ }_{* *}\right)$, Abundant $\left({ }_{* * *}\right)$, Absent (-)

membrane transport and considered a good bio-indicator of stress [35]. Similar alteration in ALT, AST, ALP and LDH was also reported by [36] Alburnus tarichi. A similar trend in L. rohita was reported by [28] Das and Mukherjee (2003) upon cypermethrin exposure. Same results were obtained by [37] in rainbow trout exposed to acute CYP, showed significant increased level of several enzymes, lactate dehydrogenase and creatine kinase.

Different histopathological studies show that if fish exposed to pesticides then gills are the first targeted organ and prime designator to show the quality of water. Many important functions beside of respiration such as regulation of acid base, regulation of ions and expelling of nitrogenous waste product in fish, gills play vital role. Fish exposure to any toxicants or pollutants were caused noteworthy damage to gills function [38].
In the present study various histopathological changes were observed in fish gills when they exposed to three different pesticide such as emamectin, acetochlor and Topsin-M. Among these changes are Epithelial lifting, destruction of cartilage core, curling, atrophy, loss of secondary gill lamellae and fusion of secondary gill lamellae which is in line with [39] reported similar histological alterations in Carassius auratus gills during chlorpyrifos toxicity. [15] reported similar changes in gills of $C$. Idella when Endosulfan was applied. Our result is in agreement with [18] Channa punctatus exposed to commercial endosulfan showed epithelial lifting, disruption of cartilage core, curling, secondary gills lamellae fusion and atrophy. Liver is a very important, playing a very important role in detoxification and play vital role in protein, carbohydrate and fat metabolism. By the accumulation of different 
pesticides, different histopathological variations shown in liver [40]. In our study, various histopathological changes observed in liver of grass carp when exposed to three chemicals (emamectin, acetochlor and topsin-M) such as necrosis, pyknosis, lymphocytes infilteration, dissolution of plasma membrane, blood congestion and vacuolation which is in agreement with [41] who reported similar histopathological alterations in the liver of Common carp on exposure to lufenuron. As reported by [15] endosulfan toxic effects on liver cells of $C$. idella showed hepatocytes swelling, pyknotic nucle $i$, vacuolations in hepatocytes, necrosis, blood vessels congestion. [42] also reported similar results in the liver of Cichlasoma dimerus. Intestine is a very sensitive organ to any contaminants which engulfed in the body because it is prime organ which come in contact with food which is contaminated with toxicants. In this study histopathological changes also appear in C. idella such as necrosis, pyknosis, rupturing of villi and excessive goblet cell formation which is in settlement with [16], reported similar histopathological changes in the intestine of Common carp on exposure to endosulfan. Our result is also in agreement with [15], reported similar kinds of alterations in intestine histology of grass Carp on treatment with endosulfan. Similar results were also obtained by [43] in Salmo salar, and in C. punctatus [44] when exposed to different concentrations of endosulfan.

Other researchers reported similar results when Oreochromis mossambicus exposed to zinc nano particles [45], Schizothorax plagiostomus exposed to Atrazine [46], Schizothorax esocinus exposed to cypermethrin [47], Schizothorax esocinus exposed to Atrazine [48], Oreochromis mossambicus exposed to Chlorpyrifos [49].

\section{Conclusion}

It could be concluded that the selected chemicals (emamectin, acetochlor and topsin-M) used in present study are higly toxic and adversly affect the haemotology, biochemistry and histopathology of grass carp and provide a strong evidence that fish and fish blood is good indicator for evaluating the pesticidal effects.

\section{Conflict of Interest}

The authors report no conflicts of interest.

\section{Acknowledgments}

This study was supported by the Higher Education Commission of Pakistan (10108).

\section{Authors Contributions}

Muhammad Fiaz Khan, Munawar Sa-leem Ahmad and Shehzad Ghayyur supervised the study. Sajid Mahmood, Naveed Akhtar and Zaib Ullah conducted the study. Sadia Tabassum and Samina Yasmin wrote the original draft. Khan Dil Badshah, Haroon Hussain and Saira review the manuscript. Alia Gul reviewed the final draft. All authors approved the final version of the manuscript.

\section{References}

1. BADROO I.A., WANI K.A., NANDURKAR H.P., KHANDAY A.H. Renewal Acute Toxicity of BroadSpectrum Herbicide, Paraquat Dichloride in Channa punctatus (Bloch). Environmental Claims Journal. 288, 2019.

2. RAJESHKUMAR S., LIU Y., ZHANG X., RAVIKUMAR B., BAI G., LI X. Studies on seasonal pollution of heavy metals in water, sediment, fish and oyster from the Meiliang Bay of Taihu Lake in China. Chemosphere. 191, 626, 2018.

3. DICKS L. Bees, lies and evidence-based policy. Nature. 494 (7437), 283, 2013.

4. SABRA F.S., MEHANA E.E. Pesticides Toxicity in Fish with Particular Reference to Insecticides. Asian Journal of Agriculture and Food Sciences. 3, 2321, 2015.

5. GROSSMAN D.M., COX D. Method for the Protection of Trees. assigned to Syngenta Crop Protection, 2010.

6. CAPRIGLIONE T., DE IORIO S., GAY F., CAPALDO A., VACCARO M.C., MORESCALCHI M.A., LAFORGIA V. Genotoxic effects of the fungicide thiophanate-methyl on Podarcis sicula assessed by micronucleus test, comet assay and chromosome analysis. Ecotoxicology. 20, 885, 2011.

7. SONG Y., SALBU B., HEIER L.S., TEIEN H.C., LIND O.C., OUGHTON D., PETERSEN K., ROSSELAND B.O., SKIPPERUD L., TOLLEFSEN K.E. Early stress responses in Atlantic salmon (Salmo salar) exposed to environmentally relevant concentrations of uranium. Aquatic Toxicology. 112, 62, 2012.

8. DHANAKUMAR S., SOLARAJ G., MOHANRAJ R. Heavy metal partitioning in sediments and bioaccumulation in commercial fish species of three major reservoirs of river Cauvery delta region, India. Ecotoxicology and Environmental Safety. 113, 145, 2015.

9. DECENA S.C.P., ARGUELLES M.S., ROBEL L.L. Assessing heavy metal contamination in surface sediments in an urban river in the Philippines. Polish Journal of Environmental Studies. 27, 1983, 2018.

10. SRIVASTAVA N., KAUSHIK N. Use of fish as bioindicator of aquatic pollution. Proceedings of the International Congress of Chemistry and Environment. 2001.

11. ISMAIL N.M., ALI S.E., MOHAMED I.K. Biochemical and histological biomarker approaches in the assessment of the water pollution in some lined and unlined watercourses of Egypt. International Journal of Fisheries and Aquatic Studies. 5, 288, 2017.

12. AMJAD M., BASHIR M.H., AFZAL M., SABRI M.A., JAVED N. Effects of Commercial Pesticides against Cotton Whitefly (Bemisia tabaci Genn.) and Mites (Tetranychus 
urticae Koch) on Growth and Conidial Germination of two species of Entomopathogenic Fungi. Pak. J. Life Social Sci. 10, 22, 2012.

13. GHAYYUR S., TABASSUM S., AHMAD M. S., AKHTAR N., KHAN M.F. Effect of Chlorpyrifos on Hematological and Seral Biochemical Components of Fish Oreochromis mossambicus. Pakistan journal of zoology. 51, 1047, 2019.

14. YOUSEFI OS., GÜNTHER M., HÖRNER M., CHALUPSKY J., WESS M., BRANDL SM., SMITH RW., FLECK C., KUNKEL T., ZURBRIGGEN M.D., HÖFER T., WEBER W., SCHAMEL W.W. Optogenetic control shows that kinetic proofreading regulates the activity of the T cell receptor. Elife. 5, 8:e42475, 2019.

15. HASAN Z., GHAYYUR S., HASSAN Z.U., RAFIQUE S. Histomorphometric and Hematological Profile of Grass Carp (Ctenopharyngodon idella) during Acute Endosulfan Toxicity. Pakistan Veterinary Journal, 35, 2015.

16. KHAN M.F., TABASSUM S., SADIQUE H., SAJID M., GHAYYUR S., BADSHAH, K.D., ULLAH I. Hematological, Biochemical and Histopathological Alterations in Common Carp during Acute Toxicity of Endosulfan. International Journal of Agriculture and Biology. 22, 703, 2019.

17. JENKINS F., SMITH, J., RAJANNA, B., SHAMEEM U., UMADEVI K., SANDHYA V., MADHAVI R. Effect of sub-lethal concentrations of endosulfan on hematological and serum biochemical parameters in the carp Cyprinus carpio. Bulletin of Environmental Contamination and Toxicology. 70, 0993, 2003.

18. DESHMUKH D. Hamatological response in a freshwater fish Channa Striatus exposed to endosulfan pesticide. 2016.

19. GEORGE A.D.I., AKINROTIMI O.A., NWOKOMA U.K. Haematological Changes in African Catfish (Clarias Gariepinus) Exposed to Mixture of Atrazine and Metolachlor in the Laboratory. Journal of Fisheries Sciences. 11, 048, 2017.

20. SINGH N.N., SRIVASTAVA A.K. Effects of endosulfan on fish carbohydrate metabolism. Ecotoxicology and Environmental Safety. 5, 412, 1981.

21. TABASSUM S., RAKHI S.F., REZA A.M., MOLLAH M.F.A., HOSSAIN Z. Potential attenuation of biochemical parameters and enzymatic functions in Cyprinus carpio fingerlings by Phenthoate 50 EC insecticide exposure. Environmental Science and Pollution Research. 27, 35837, 2020.

22. VANI T., SAHARAN N., MUKHERJEE S., RANJAN R., KUMAR R., BRAHMCHARI R. Deltamethrin induced alterations of hematological and biochemical parameters in fingerlings of Catla catla (Ham.) and their amelioration by dietary supplement of vitamin C. Pesticide Biochemistry and Physiology. 101, 16, 2011.

23. AKHTAR N., KHAN M.F., TABASSUM S., ZAHRAN E. Adverse effects of atrazine on blood parameters, biochemical profile and genotoxicity of snow trout (Schizothorax plagiostomus). Saudi journal of biological science. 28, 1999, 2021.

24. KAVITHA C., RAMESH M., KUMARAN S.S., LAKSHMI S.A. Toxicity of Moringa oleifera seed extract on some hematological and biochemical profiles in a freshwater fish, Cyprinus carpio. Experimental and Toxicologic Pathology. 64, 681, 2012.

25. SALEH Y.S., MARIE S. Use of Arius thalassinus fish in a pollution biomonitoring study, applying combined oxidative stress, hematology, biochemical and histopathological biomarkers: A baseline field study. Marine Pollution Bulletin. 106, 308, 2016.

26. AKHTAR N, KHAN M.F., TABASSUM S. Sub Lethal Effects of Atrazine on Hematology, Histopathology and Biochemistry of Chirruh Snowtrout (Schizothorax esocinus). Journal of Animal and Plant Sciiences. 29, 1447, 2019.

27. SUVETHA L., RAMESH M., SARAVANAN M. Influence of cypermethrin toxicity on ionic regulation and gill $\mathrm{Na}^{+} /$ $\mathrm{K}^{+}$-ATPase activity of a freshwater teleost fish Cyprinus carpio. Environ. Toxicol. Pharmacol. 29, 44, 2010.

28. DAS B.K., MUKHERJEE S.C. Toxicity of cypermethrin in Labeo rohita fingerlings: biochemical, enzymatic and hematological consequences. Comp Biochem. Physiol. 134C, 109, 2003.

29. QADIR S., LATIF A., ALI M, IQBAL F. Effects of imidacloprid on the hematological and serum biochemical profile of Labeo rohita. Pakistan J. Zool. 46, 1085, 2014.

30. AKHTAR N., KHAN M.F., TABASSUM S. Effects of cypermethrin on the hematological parameters, biochemical components of blood and histopathological changes in different organs of chirruh snow trout (Schizothorax esocinus). Pakistan Journal of Zoology. 53, 943, 2021.

31. BLAHOVA J., MODRA H., SEVCIKOVA M., MARSALEK P., ZELNICKOVA L., SKORIC M. SVOBODOVA Z. Evaluation of Biochemical, Haematological and Histopathological Responses and Recovery Ability of Common Carp (Cyprinus carpio L.) after Acute Exposure to Atrazine Herbicide. BioMed Research International. 980948, 8, 2014.

32. AHMAD Z., AL-KHALID A., AL-BALAWI A., ALMISNED F., MAHBOOB S. Study of acute toxicity, haematological and biochemical alterations induced by the exposure of DDT of Catfish. Fresenius Environmental Bulletin. 25, 5935, 2016.

33. RAMESH M., SRINIVASAN R., SARAVANA M. Effect of atrazine (Herbicide) on blood parameters of common carp Cyprinus carpio (Actinopterygii Cypriniformes). African Journal of Environmental Science and Technology. 3, 453, 2009.

34. BORGES A., SCOTTI L.V., SEQUEIRA D.R., ZANINI R., AMARAL F., JURINITIZ D.F., WASSERMANN G.F. Changes in hematological and biochemical value in Jundia Rhamdia quelen due to sub lethal toxicity of cypermethrin. Chemosphere. 69, 920, 2007.

35. BANAEE M., MIRVAGHEFEI A.R., MAJAZI B., RAFEI G.R., NEMATDOST B. Hematological and histopathological study of experimental Diazinon poisoning in common carp fish (Cyprinus carpio). Iranian J. Nat. Resour. 64, 1, 2011.

36. KIRACCAKALI A.N., OGUZ A.R. Determination of cytotoxic, genotoxic, and oxidative damage from deltamethrin on primary hepatocyte culture of Lake Van fish, Alburnus tarichi. Chemistry and Ecology. 36, 651, 2020.

37. VELISEK J., WLASOW T., GOMULKA P., SVOBODOVA Z., DOBSIKOVA R., NOVOTNY L., DUDZIK M. Effects of cypermethrin on rainbow trout (Oncorhynchus mykiss). Vet. Med. 51, 469, 2006

38. BANTU N., KUMARI N., VAKITA R. Histological Alteration in Different Tissues of Indian major carp, Labeo rohita (Hamilton) exposed to Profenofos 50\% EC and Carbosulfan 25\% EC formulations. Journal of Biology and Today's World. 6, 38, 2017. 
39. MACIRELLA R., SESTI S., BERNABÒ I., TRIPEPI M., GODBERT N., BRUNELLI E. Lead toxicity in seawater teleosts: A morphofunctional and ultrastructural study on the gills of the Ornate wrasse (Thalassoma pavo L.). Aquatic toxicology. 211, 193, 2019.

40. SHARMA A., MISHRA M., SHUKLA A.K., KUMAR R., ABDIN M.Z., CHOWDHURI D.K. Organochlorine pesticide, endosulfan induced cellular and organismal response in Drosophila melanogaster. J. Hazard. Mater. 221-222, 275, 2012.

41. GHELICHPOUR M., MIRGHAED A.T., HOSEINI S.M., JIMENEZ A.P. Plasma antioxidant and hepatic enzymes activity, thyroid hormones alterations and health status of liver tissue in common carp (Cyprinus carpio) exposed to lufenuron. Aquaculture. 516, 734634, 2020

42. CUNA R.H., VAZQUEZ G.R., PIOL M.N., GUERRERO N.V., MAGGESE M.C., NOSTRO F.L.L. Assessment of the acute toxicity of the organochlorine pesticide endosulfan in Cichlasoma dimerus (Teleostei, Perciformes). Ecotoxicology and Environmental Safety. 74, 1065, 2011.

43. GLOVER C.N., PETRI D., TOLLEFSEN K.E., JØRUM N., HANDY R.D., BERNTSSEN M.H. Assessing the sensitivity of Atlantic salmon (Salmo salar) to dietary endosulfan exposure using tissue biochemistry and histology. Aquatic Toxicology. 84, 346, 2007.

44. HALOI K., KALITA M., NATH R. The Study on the Histopathological Changes of Stomach of Channa punctatus Bloch. By Used Pesticide Endosulfan. Global Journal of Human-Social Science Research. 2013.
45. KHAN G.B., AKHTAR N., KHAN M,F., ULLAH Z., TABASSUM S., TEDESSE Z. Toxicological impact of Zinc Nano Particles on tilapia fish (Oreochromis mossambicus). Saudi Journal of Biological Science. 2021.

46. AKHTAR N., KHAN M.F., TABASSUM S., ZAHRAN E. Adverse effects of Atrazine on Blood parameters, Biochemical Profile and Genotoxicity of snow trout (Schizotho-rax plagiostomus). Saudi journal of biological science, 28 (3), 1999, 2021.

47. AKHTAR N., KHAN M.F., TABASSUM S. Effects of Cy-permethrin on the Hematological Pa-rameters, Biochemical Components of Blood and Histopathological Changes in Different Organs of Chirruh Snow Trout (Schizothorax esocinus). Pakistan Journal of Zoology. 53 (3), 943, 2021.

48. AKHTAR N., KHAN M.F., TABASSUM S. Sub Lethal Effects of Atrazine on Hematology, Histopathology and Biochemistry of Chirruh Snowtrout (Schizothorax esocinus). The J. Anim. Plant Sci. 29 (5), 1447, 2019.

49. GHAYYUR S., AHMAD M.S., TABASSUM S., AKHTAR N., KHAN M.F. Effect of Chlorpyrifos on Hematological and Seral Biochemical Components of Fish Oreochromis mossambicus. Pakistan Journal of Zoology, 51 (3), 1047, 2018. 